\title{
Editorial for the Special Issue on Nutritional Requirements in New Fish Species under Culture
}

\author{
Francisco Javier Moyano \\ Department of Biology and Geology, Engineering School, University of Almería, 04120 Almería, Spain; \\ fjmoyano@ual.es
}

Received: 19 March 2018; Accepted: 19 March 2018; Published: 23 March 2018

Keywords: nutrition; energy; protein requirements; practical diets; growers; feeds evaluation

The worldwide interest in developing the culture of nonconventional fish species determines the need to increase knowledge in different aspects of their basic physiology, as well as in the application of such information into practical protocols to be used in their feeding, reproduction, and general handling. In this sense, the papers included in the present special issue are focused on some important aspects related to the nutrition and feeding of several of those species.

From a basic perspective, Martínez-Cárdenas et al. [1] carried out a partial characterization of digestive proteases in the green cichlid, Cichlasoma beani, as a detailed knowledge of the digestive biochemistry of a new species is a prerequisite, both to get a good comparison with the digestive physiology in already produced fish species, and to help in the selection of the more suitable ingredients to be used in feeds. In this case, results suggest that $C$. beani is an omnivorous fish with carnivorous tendencies. Also, Mozanzadeh et al. [2] developed this basic and comparative knowledge in their work "Macronutrient requirements of silvery-black porgy (Sparidentex hasta): a comparison with other farmed sparid species". The authors performed a comprehensive review on the published studies on the nutritional needs of this promising fish species for aquaculture diversification in the Persian Gulf and Oman Sea regions. They offer detailed information on the different nutritional needs for the species, but conclude that future studies need to be conducted using a more holistic approach under intensive farming conditions to refine current knowledge on the nutrient requirements of this species.

From a more applied perspective, Frías-Quintana et al. [3] presented their results about the use of potato starch in diets of tropical gar (Atractosteus tropicus, Gill 1863) larvae. Their objective was to assess the possibility of reducing protein use in diets for larviculture of this species, and they concluded that the dietary inclusion of potato starch might enhance growth and survival and decrease cannibalism during such initial stages. In this same line, the study by Enyidi et al. [4] was oriented to develop practical diets for the African catfish Clarias gariepinus, and they tested the possibility of reducing the amount of fishmeal in practical diets for this species through the use of vegetable meals from bambaranut (Voandzeia subterranea) and soybean (Glycine max). They concluded that both plant meals are nutritionally equivalent, and can partly substitute fishmeal in the diets of African catfish.

All these studies increase our knowledge in the abovementioned issues and represent valuable contributions to the highly developing field of fish culture.

\section{References}

1. Martínez-Cárdenas, L.; Álvarez-González, C.A.; Hernández-Almeida, O.U.; Frías-Quintana, C.A.; Ponce Palafox, J.T.; Castillo-Vargasmachuca, S. Partial Characterization of Digestive Proteases in the Green Cichlid, Cichlasoma beani. Fishes 2017, 2, 4. [CrossRef] 
2. Torfi Mozanzadeh, M.; Marammazi, J.G.; Yaghoubi, M.; Agh, N.; Pagheh, E.; Gisbert, E. Macronutrient Requirements of Silvery-Black Porgy (Sparidentex hasta): A Comparison with Other Farmed Sparid Species. Fishes 2017, 2, 5. [CrossRef]

3. Frías-Quintana, C.A.; Álvarez-González, C.A.; Tovar-Ramírez, D.; Martínez-García, R.; Camarillo-Coop, S.; Peña, E.; Galaviz, M.A. Use of Potato Starch in Diets of Tropical Gar (Atractosteus tropicus, Gill 1863) Larvae. Fishes 2017, 2, 3. [CrossRef]

4. Enyidi, U.D.; Pirhonen, J.; Kettunen, J.; Vielma, J. Effect of Feed Protein: Lipid Ratio on Growth Parameters of African Catfish Clarias gariepinus after Fish Meal Substitution in the Diet with Bambaranut (Voandzeia subterranea) Meal and Soybean (Glycine max) Meal. Fishes 2017, 2, 1. [CrossRef]

2018 by the author. Licensee MDPI, Basel, Switzerland. This article is an open access article distributed under the terms and conditions of the Creative Commons Attribution (CC BY) license (http://creativecommons.org/licenses/by/4.0/). 